PRZEGLĄD NAUK HISTORYCZNYCH 2020, R. XIX, NR 2

https://doi.org/10.18778/1644-857X.19.02.04

NGUYen VAn SAng

The University Of DA NANG*

iD https://orcid.org/0000-0003-3486-757X

Jolanta A. Daszyńska

UNIVERSITY OF LODZ**

iD https://orcid.org/0000-0001-9108-1296

\title{
The problem of the abolition of slavery and maritime rights on U.S. vessels with regards to British-American relations in the first half of the $19^{\text {th }}$ century ${ }^{1}$
}

\begin{abstract}
The article analyses the struggle of Anglo-American relations connected to slaves and maritime rights on the sea from 1831 to 1842 . The study is based on monographs, reports, treaties and correspondences between the two countries from the explosion of the Comet case in 1831 to the signing of the Webster-Ashburton treaty in 1842. This study focuses on three fundamental issues: the appearance of Comet, Encomium, Enterprise, Hermosa and Creole as international incidents with regards to British-American relations; the view of both countries on the abolition of slavery, maritime rights as well as the dispute over issues to resolve arising from these incidents; the results of British-American diplomacy to release slaves and maritime rights after the signing of the WebsterAshburton treaty. The study found that the American slave ships were special cases in comparison with the previous controversies in bilateral relations. The American slave vessels sailed to the British colonies due to bad weather conditions and a slave rebellion on board. In fact, Great Britain and the United States had never dealt with a similar case, so both sides failed to find a unified view regarding the differences in the laws and policies of the two countries on slavery. The history of British-American relations demonstrated that under the pressures

* University of Science and Education, Faculty of History, Department of World History, e-mail: nvsang@ued.udn.vn

** Faculty of Philosophy and History, Institute of History, Department of Modern History, e-mail: joladaszynska@wp.pl

1 This research is funded by Vietnam National Foundation for Science and Technology Development (NAFOSTED) under grant number 601.02-2020.303.
\end{abstract}


of the border dispute in Maine and New Brunswick, the affairs were not resolved. In addition, it could have had more of an impact on the relationship between the two countries, eventually $\mathrm{p}$ the two countries into a war. In that situation, the diplomatic and economic solutions given to the abolition of slavery and maritime rights were only temporary. However, the international affairs related to the American slave vessels paved the way for the settlement of maritime rights for British-American relations in the second half of $19^{\text {th }}$ century.

Keywords: Great Britain, the United States of America, Comet, Encomium, Enterprise, Hermosa, Creole, Daniel Webster, Lord Ashburton, slavery, maritime rights.

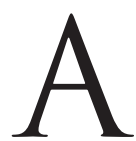

merican President Andrew Jackson declared that with Great Britain, we can look forward to an era of peace, competition and honor. Any historical condition of the two countries is considered [...] to bring confidence to both, that it is the policy to maintain the friendliest relationship ${ }^{2}$. The British government also acknowledged that friendship with the United States is a great asset $^{3}$. The Jackson and Castlereagh's statements mentioned above showed how important Great Britain and the United States were to the foreign policy of each country after the American Revolutionary War (1775-1783). The Proclamation of Neutrality in 1793, George Washington's Farewell Address in 1796, and especially the introduction of the Monroe Doctrine in 1823, affirmed the United States' neutral foreign policy. Since the declarations, political, territorial and maritime conflicts between Great Britain and the United States were replaced by seeking peaceful solutions and developing friendly trade exchanges. Washington's successors, from John Adams to James Buchanan, continued to look for solutions to build a good relationship with Great Britain and to prevent political conflicts, territorial and maritime rights disputes, and the abolition of slavery in particular. In terms of political conflict, Great Britain and the United States' reconstruction efforts failed to prevent the two countries from having political conflicts due to the British favoring Indian tribes over the policy of expanding the Northwestern territory of the United States, restricting neutral trade rights of US merchant ships, and arguing about American support for the

2 First Annual Message, https://www.presidency.ucsb.edu/documents / firstannual-message-3 (online: 18 IV 2019).

${ }^{3}$ B. Perkins, Castlereagh and Adams: England and the United States, $1812-$ 1823, California 1964, pp. 61, 197; B. Perkins, The Cambridge History of American Foreign Relations, vol. I (The Creation of a Republican Empire, 1776-1865), New York 1985, p. 208. 
rebellions in British Canada. In terms of territorial disputes, the two sides strived to expand their influence in sovereignty disputes in Oregon, California, Hawaii and the merger of the Republic of Texas. Concerning interests in the border areas, the two sides also had deep contradictions, even on the verge of a military war related to a dispute over the Northeast border between Maine and New Brunswick. However, after the war of independence, the United States was a country that recognized slavery in some Southern states while Great Britain was the pioneer nation fighting against slavery at sea starting in 1807 and then the entire British Empire in 1834. Therefore the slave trade was viewed differently by each country. This led to a struggle in Anglo - American relations in the first half of the $19^{\text {th }}$ century.

In the 1830s, the demand for labour formed slave trade centres in the Southern United States, in which New Orleans was the most important port ${ }^{4}$. In fact, all American slave vessels from New Orleans traveling to other domestic ports had to pass through the waters of British colonies in the Caribbean. The British government abolished slavery in their colonies in August 18345. That was the fundamental cause of international incidents involving American slave brigs in Anglo-American relations. The Comet, Encomium, Enterprise, Hermosa and Creole ships were typical cases related to the abolition of slaves and maritime rights on the sea in the first half of the $19^{\text {th }}$ century ${ }^{6}$.

${ }^{4}$ In this period, Isaac Franklin (1789-1846) and John Armfield (1797-1871) were famous slave traders. They were among the first to apply modern business methods to slave trading. Franklin and Armfield owned several slave vessels to transport their slaves from Virginia to New Orleans. Coastal slave steamboats were used to transport about 150 slaves and travelled in the months between October and May when temperatures were bearable. See D.L. Lib by, Slavery and Frontier Mississippi, 1720-1835, Mississippi 2004, p. 64; J. How e11, John Armfield, Slave-trader, "Tennessee Historical Quarterly" 1943, vol. II, No. 1, pp. 3-29.

5 The Slavery Abolition Act of 1833 as known as An Act for the Abolition of Slavery throughout the British Colonies; for promoting the Industry of the manumitted Slaves; and for compensating the Persons hitherto entitled to the Services of such Slaves. The Act was adopted by the British on August $28^{\text {th }}, 1833$ and officially entered into force on August $1^{\text {st }}, 1834$, consisting of two basic contents which was the declaration of slavery abolition in the entire British empire, except for the territories owned by the East India Company, Ceylon Island (presently Srilanka), and Saint Helena and compensation for slave owners who lost slaves. See The Slavery Abolition Act of 1833, https://www.thehistorypress.co.uk/articles/the-slavery-abolition-act-of-1833/ (online: 20 I 2019); Slavery Abolition Act, https:/ /www. britannica.com/topic/Slavery-Abolition-Act (online: 20 I 2019).

${ }^{6}$ See C.G. Wo o d s o n, The Negro in Our History, Washington 1922, p. 208. 
In October 1830, the Comet vessel, under the command of Captain Isaac Staples, sailed from Alexandria to New Orleans carrying 164 slaves $^{7}$. The ship had to pass through the British Bahamas ${ }^{8}$. On January $2^{\text {nd }}, 1831$, due to bad weather, the Comet had to enter British waters and was trapped in the coral reef of the Abaco Islands in the Northern Bahamas. Those who salvaged the shipwrecks brought all of the crew, passengers and all of the slaves on board to the port of Nassau, New Providence. The ship was then taken to this port on February $11^{\text {th }}, 1831$. Immediately upon arriving in Nassau, the Comet's captain quickly took the appropriate steps to prevent the slaves from going ashore ${ }^{10}$. All slaves remained on the rescue ship with 15 others in order to prevent them from escaping. Those remaining on board were watched by Captain Staples. Before the ship left, the British colonial government declared

7 All of the Comet's 164 slaves were covered by three insurance companies in New Orleans with a total value of 71,330 dollars. The insurance companies were The Louisiana State Insurance Company, The Mississippi Marine and Fire Insurance Company, and The Merchant's Insurance Company of New Orleans. They aimed to protect their assets from being seized by the arrest policies of foreign powers. See Letter of Van Buren to Lord Palmerston, February 25, 1832, [in:] Message from the President of the United States, $24^{\text {th }}$ Congress, $2^{\text {nd }}$ Section, No. 174, 1835, p. 9.

8 The Bahamas are a country on the Northwest edge of the West Indies. Formerly a British colony, the Bahamas became an independent nation in the Commonwealth in 1973. For Bahamas's history see more Our History, https://www. bahamas.com/our-history (online: 12 I 2019); The Bahamas Islands, West Indies, https://www.britannica.com/place/The-Bahamas (online: 11 I 2019).

9 The Comet encountered bad weather without the sun or other celestial bodies that could serve as a basis for controlling the ship. In Abaco, sailors thought that the ship was too far from its current location. At 10 p.m. on January 3, 1831 the ship was stranded in coral reefs 8 to 10 miles from the coast of Abaco, Bahamas. Early the next morning, the ship was discovered and taken to the Bahamas. See S. Riley, T.B. Peters, Homeward Bound: A History of the Bahamas Islands to 1850 with a Definitive Study of Abaco in the American Loyalist Plantation Period, Florida 2000, p. 212; J.L. Sch e rm erh or n, The Business of Slavery and the Rise of American Capitalism, 1815-1860, New Haven-London 2015, p. 146.

${ }^{10}$ Upon arriving in Nassau, Smith, the Captain of the Comet, conducted a transaction agreeing to pay 4,000 dollars to rent a ship with all possible means to transport the slaves to New Orleans. However, before this intention was made, customs office officials announced that the slaves would be seized until they received the opinion of the Governor and the colonial lawyers regarding this issue. They stated that their responsibility was to keep the ship under British law regarding the abolition of the slave trade. See Letter of Van Buren to Lord Palmerston, February 25, $1832 \ldots$, pp. 8-9. 
freedom for all of the slaves aboard ${ }^{11}$. According to documents, 5 of the 164 slaves chose to return as slaves to the United States ${ }^{12}$.

Soon after, slave owners implored President Andrew Jackson to obtain compensation from the British government for the lost slaves. Jackson agreed ${ }^{13}$. In December 1831 , Jackson's administration sent a formal request to the British government for compensation to the slave owners ${ }^{14}$. President Jackson immediately directed Martin Van Buren, the Secretary of State, to send instructions to the Minister of the United States in London on this issue ${ }^{15}$. The diplomatic notes were sent to Great Britain with the aim of quickly bringing the matter to a conclusion ${ }^{16}$. On February $25^{\text {th }}, 1832$, Buren sent a dispatch to Lord Palmerston, the British Secretary of State for Foreign Affairs. In the dispatch, Van Buren presented the process of the Comet and justified the evidence, making a claim for compensation. The reason stated was that at the time the Comet encountered an accident at sea near Abaco. Saving the ship from sinking, starvation and protecting life aboard was a humanitarian principle. In addition, the ship was brought into the port of Nassau under the jurisdiction and protection of the local government. This was the basis for confirming that the slave transport of the Comet was not importing slaves into British colonies, which was prohibited by British law. Therefore, the seizure and

${ }^{11}$ During the repair, 11 slaves fled the ship, but they were then returned to the ship by the local authorities. See D.J. Libby, op. cit., p. 64.

12 See J. Levy, Freaks of Fortune: The Emerging World of Capitalism and Risk in America, Massachusetts 2012, p. 27.

13 At the same time, Andrew Stevenson (1784-1857) was a representative in London sending a letter to the British government requesting compensation to slave holders. In his correspondence, he asserted that "under the Constitution of the United States, slaves are regarded as property and that there is in fact no distinction between 'property' in person and 'property in things'. See J.R. Gid dings, History of the Rebellion: Its Authors and Causes, New York 1864, pp. 174-175.

${ }^{14}$ R.W. Remini, Andrew Jackson: The Course of American Democracy, 18331845, Baltimore-London 1984, p. 200.

15 According to statistics, between 1832 and 1836, the United State Department of State sent 6 instructions to United States representatives in London and more than 25 official letters, correspondences between the Ministry of the two parties regarding the cases of the Comet and the Enterprise. See List of Accompanying Papers..., p. 2.

16 See W. W o od e11, Slavery and Anti-slavery: A History of the Great Struggle in both Hemispheres with a view of the Slavery Question in the United States, New York 1852, p. 258. 
release of slaves aboard the Comet in the Bahamas was illegal ${ }^{17}$. Van Buren's claim was sent to royal law officials for consideration. However, after 4 months, the claim still made no new progress ${ }^{18}$.

In the following year, Martin Van Buren's request for compensation to slave owners in the case of the Comet continued to be petitioned by Aaron Vail, Chargé d'affaires of the United States in London to Palmerston and George Shee, an official of the Secretary of State for Foreign Affairs ${ }^{19}$. However, Palmerston continued to answer that the claim was still under consideration by their lawyers and continued to make promises without any specific action ${ }^{20}$. In response to the delay of the British government, Americans continued to press the issue through Vail's role and hoped that Great Britain would accelerate the process of settling the case of the

17 Governor Smith of the British Bahamas said that the whole incident was reported to the British government. The action was based on British government orders. The British government must be responsible for compensating for such damage. At this time, Lord Palmerston acted as a preventative who presented the slave owners' claim to the British government for the consequences they had suffered due to the action of the British colonial government in the Bahamas related to the release of slaves. See Letter of Martin Van Buren to Lord Viscount Palmerston, February 25 ${ }^{\text {th }}$, 1832, [in:] Message from the President of the United States, $24^{\text {th }}$ Congress, $2^{\text {nd }}$ Section, No. 174 , Washington 1835 , pp. 7-15.

18 Aaron Vail sent letters to Edward Livingston twice to report on the British settlement regarding Van Buren's claim on February $25^{\text {th }}, 1832$. In his letter dated July $15^{\text {th }}$, 1832, Vail announced that, George Shee, an official of the British Ministry of Foreign Affairs replied that Van Buren's claim was transferred to royal lawyers for their opinions regarding the points of law related to the above case. In the second letter sent on November $14^{\text {th }}, 1832$, Vail expressed his regret that Van Buren's claim was still at the royal law office. The British side only promised to find out the cause of the delay and did not give any further progress. See $E x$ tract of a letter from Aaron Vail to Edward Livingston, July 15 ${ }^{\text {th }}, 1832$, [in:] ibidem, p. 15; Extract of a letter from Aaron Vail to Edward Livingston, November $14^{\text {th }}, 1832$, [in:] ibidem, pp. 15-16.

19 Aaron Vail (1796-1878) was an American diplomat, who served as the Chargé d'Affaires to Spain between 1832 and 1836 and from 1840 to 1842 . He was appointed as a Minister of the United States in Great Britain by Van Buren from 1832 to 1836. See Aaron Vail (1796-1878), https:/ / history.state.gov/departmenthistory/people/vail-aaron (online: 12 I 2019); American Ambassadors to the United Kingdom, https://uk.usembassy.gov/our-relationship/rcambex/ (online: 12 I 2019).

20 See Extract of a letter from Aaron Vail to Edward Livingston, March $30^{\text {th }}$, 1833, [in:] Message from the President of the United States, $24^{\text {th }}$ Congress, $2^{\text {nd }}$ Section, No. 174, 1835, p. 16; Letter from Aaron Vail to Lord Viscount Palmerston, March 25th 1833, [in:] ibidem, pp. 16-17; Extract of a letter from Aaron Vail to the Secretary of State, April 6 ${ }^{\text {th }}$, 1833, [in:] ibidem, pp. 17-18; Letter from Lord Viscount Palmerston to Aaron Vail, March 30 ${ }^{\text {th }}$, 1833, [in:] ibidem, p. 18. 
Comet $^{21}$. By early 1834, the United States used various means to request that Great Britain consider the Comet, but all suggestions were rejected for the sole reason that they were still under consideration $^{22}$. While the case of the Comet had not been resolved by Great Britain, the Encomium incident in early 1834 made the relationship between the two countries more stressful.

The Encomium was captained by Paschal Sheffield, who was tasked with carrying out the journey from Charleston to New Orleans in January 1834 with 45 slaves aboard. On February $4^{\text {th }}$, 1834, the ship was wrecked on Abaco Island. Similar to the Comet, a Bahamian rescue ship also sent the ship to Nassau and freed all the slaves on board ${ }^{23}$.

The liberation of slaves aboard the Comet and Encomium caused strong agitation in the United States, especially in the South, where it was seen as a direct interference with their property rights. On August $2^{\text {nd }}, 1834$, John Forsyth sent a letter to Vail to give the President's instructions about the need to talk to Great Britain regarding the two cases mentioned above. At the same time, the instructions also included a claim for compensation from the British government for the slaves freed from the Comet and the Encomium because it involved the friendly relationship between the two countries, preventing any similar harmdoing in the future between the two countries ${ }^{24}$. The United States continued to put pressure on Great Britain to establish a delegation in order to resolve the issue with the Comet and to ask for compensation. The United States also advocated for the legality of the slaves on the Encomium and its similarity to the Comet ${ }^{25}$. A short time after the first claim was

${ }^{21}$ See Letter from Aaron Vail to Lord Viscount Palmerston, April $4^{\text {th }}$, 1833, [in:] ibidem, pp. 18-20.

22 The United States proposed a British delegation to participate in negotiations with the United States. See Letter from Lord Viscount Palmerston to Aaron Vail, April 24th , 1833, [in:] ibidem, p. 21; Extract of a dispatch from Aaron Vail to McLane, January 14 ${ }^{\text {th }}, 1834$, [in:] ibidem, pp. 21-22.

${ }^{23}$ Balfour, Nassau's governor, in the letter to the British government in London reported on the case of the Encomium. He pointed out that 69 Americans came from the ship wrecked in Abaco, of which 45 were slaves. He expressed his desire to free all the slaves and there were 41 or 42 people who wanted to stay there.

${ }^{24}$ See Letter from John Forsyth to Aaron Vail, August $2^{\text {nd }}, 1834$, [in:] Message from the President of the United States, $24^{\text {th }}$ Congress, $2^{\text {nd }}$ Section, No. 174, Washington 1835 , p. 6.

${ }^{25}$ See Letter from Aaron Vail to Lord Viscount Palmerston, September $22^{\text {nd }}, 1834$, [in:] ibidem, pp. 25-33. 
sent to the British government, the United States admitted defeat in demanding Great Britain to accelerate the process of establishing a delegation to resolve the issue with the Comet, but hoped that there would be a final decision on both cases. On September $22^{\text {nd }}$, 1834, a dispatch was sent to Palmerston by Vail to petition Great Britain to resolve the slave ship owners' complaint ${ }^{26}$. However, no progress was made. Meanwhile, the case of the Enterprise in early 1835 made the relationship between the two countries even more complicated.

The Enterprise ${ }^{27}$ travelled from Columbia to Charleston, South Carolina on January 22 $2^{\text {nd }}, 1835$ carrying 78 slaves on board ${ }^{28}$. During the voyage, the ship encountered storms, leaks, and at the same time their food and water were depleted. So the ship was brought into Hamilton, Bermuda to avoid storms and to be resupplied and repaired. On February $11^{\text {th }}, 1835$, the ship was taken to Hamilton Harbour in Bermuda ${ }^{29}$. Upon arriving in Bermuda, the captain ordered that no one on shore was allowed to communicate

${ }^{26}$ See Extract of a dispatch from Aaron Vail to the Secretary of State of the United States, September 22 ${ }^{\text {nd }}$, 1834, [in:] Register of Debates in Congress: Comprising the leading debates and incidents of the second session of the Eighteenth Congress, vol. X, Washington 1834, p. 260.

27 The history of the ship before the incident still has not been clearly defined. The documents refer to several ships with the same name as the Enterprise. The first ship was built in 1805 in Hanover, Massachusetts. This ship surrendered to foreign countries in 1843 and was lost. This proved that it was not the Enterprise that encountered incident in the Bahamas because the Enterprise operated until 1835. Another ship was built in Berkeley, Massachusetts in 1825, operated from New Orleans to Pensacola throughout the 30s. It could be the Enterprise, although its voyage was not the same as the Enterprise which encountered the storm in the Bahamas. The third ship was a sloop with a tonnage of 27 tons built in 1825 in Currituck County, North Carolina, the captain was John O. Hoast. However, this ship was too small for long voyages along the coast. See J.R. Kerr-Ritchie, Rebellious Passage: The Creole Revolt and America's Coastal Slave Trade, Cambridge 2019, p. 70 .

${ }^{28}$ Among 78 passengers, there were 41 women, 37 men, the oldest was 31 years old, and the youngest was 5 months old. The average age was 9-15 and 19 to 25 years old. 44 slaves or more than half were in the age of 20 or younger. Many of them were relatives. In addition, there were 127 tons of goods on board. See G. Horne, Negro Comrades of the Crown: African Americans and the British Empire Fight the US before Emancipation, New York 2012, p. 108.

${ }^{29}$ When customs officers checked the ship, they discovered that the brig smelled of 78 slaves on board and in unsanitary condition. However, in the statement Captain Elliot Smith did not mention the slaves but only listed items transported by the ship. Nassau customs officers later informed Smith of Nassau's abolition status and the handling plan for the Enterprise. See Bermuda's History 
with the slaves. On February $19^{\text {th }}, 1835$, the necessary supplies were fully prepared, the sails had been repaired, and the ship was ready to sail. However, the ship was kept at anchorage in the harbour and was not taken by Bahamian authorities to the dock to set sail ${ }^{30}$. At 6 p.m. on February 19 ${ }^{\text {th }}, 1835$, the Chief Judge of Bermuda sent a request to bring the slaves to court. The Chief Judge interviewed each person and asked them if they would like to stay and be free in Bermuda under the government's rule and protection or continue their journey to where they were going. There were 72 slaves who wished to be free and stay in Bermuda, except for a woman named Matilda Ridgely and her five young daughters Ann, Betsey, Helen, Mahaley and Martha who wanted to return to the United States as slaves ${ }^{31}$. Those who stayed received 70 dollars to help integrate into society ${ }^{32}$.

On January $7^{\text {th }}, 1837$, Lord Palmerston sent a dispatch to Andrew Stevenson, Minister of the United States in London ${ }^{33}$. In this dispatch, Palmerston made conclusions regarding the cases of the

from 1800 to 1899, http://www.bermuda-online.org/history1800-1899.htm (online: 11 II 2019).

30 Captain Elliot Smith and his agent met the repairers. They said that they had received an order from the council to detain the ship's papers until receiving instructions from the governor of the Bahamas. On February $19^{\text {th }}$, 1835, Captain Smith vehemently protested against the detention of papers by the Bermuda authority. He worried that the colored people in Hamilton would board the ship at night and rescues the slaves. See J.B. Moore, History and Digest of the International Arbitrations to which the United States Has Been a Party: Together with Appendices Containing the Treaties Relating to Such Arbitrations, and Historical and Legal Notes on Other International Arbitrations Ancient and Modern, and on the Domestic Commissions of the United States for the Adjustment of International Claims, vol. IV, Washington 1898, p. 4372.

${ }^{31}$ Due to a lack of explanation for Matilda's decision, the Attorney General of the Bahamas also cannot explain why Matilda decided to return to the United States. He made the assumption that the family at the United States plantation or the slave owner's kindness could be the reason for this decision. However, James Cullum had the opinion that Matilda Ridgely had to choose between freedom and returning home to her other children in the United States. Finally, she decided to return to the United States. See J.R. Kerr-Ritchie, op. cit., p. 72; Artist to Depict Alexandria's History with Slave Ship "Enterprise", https://www.alxnow. com/2020/01/17/artist-to-depict-alexandrias-history-with-slave-ship-enterprise/ (online: 12 I 2019).

${ }^{32}$ See Seizure of American Slaves in Bermuda, [in:] The African Repository and Colonial Journal, vol. XI, published by the American Colonization Society, Washington 1835, p. 90.

${ }^{33}$ Andrew Stevenson was appointed as Minister of the United States to Great Britain from July $13^{\text {th }}, 1836$ to October $21^{\text {st }}$, 1840, replacing Aaron Vail. See 
Comet, the Encomium and the Enterprise. Palmerston stated that the British government considered the claims for compensation from the slave owner of the Enterprise as unfounded, but in the case of the Comet and the Encomium it was completely grounded. The British government affirmed the view that it would consider compensation to all legitimate slave owners that were harmed by the British colonial government. At the discretion of the British government, owners of the slaves on the Enterprise were never legally in possession of these slaves in British territory. Before the Enterprise came to Bermuda, slavery was abolished in all of the territories of the British Empire. The British government declared that, this consideration of the claim for the slaves on the Enterprise was the final decision, based on the above principles. Since that time, no such claim for the Enterprise was accepted. However, acquiring compensation for the case of the Comet was allowed ${ }^{34}$. The British government argued that in 1831 slavery was still accepted in the Bahamas and slave ownership was recognized by law. Foreigners were also legally allowed to possess slaves on these islands so long as they did not violate any of the laws on slavery set forth there. Therefore, the relationship between slaves and slave owners did not need to be abolished at that time in the colony. The seizure of the ship by British authorities was illegal. If not for this intervention, the ship could have continued its journey to the port they had intended. Regarding the Encomium, Palmerston explained

Andrew Stevenson, https://history.house.gov/People/Listing/S/STEVENSON, -Andrew-(S000891)/ (online: 12 I 2019).

34 Palmerston presented that when the Encomium was wrecked, the slaves were still allowed to stay in the Bahamas. There was no doubt that, without the intervention of a division of the British authorities, the ship could continue on its journey. Palmerston also pointed out that the British government had already grasped the value of the slaves freed from the Comet and Encomium because they were still in the Bahamas. The compensation would be considered and discussed with the slave owners for the damages caused by the colonial government to them. The British side asked the United States to support the slave owners of the two ships mentioned above in determining the value of the slaves. At the same time they stated that slavery was abolished throughout the British Empire, therefore since that time there would be no basis to consider compensating for the treatment of slaves under any circumstances, who may go into British colonies, or may be brought to Great Britain. See A Dispatch from Lord Viscount Palmerston to Stevenson, January $7^{\text {th }}, 1837$, [in:] Message from the President of the United States, in compliance..., p. 15. 
that the British government considered this case to be no different from the case of the Comet ${ }^{35}$.

In response to decision, the United States said that the British government was indecisive and flippant to all three cases mentioned above ${ }^{36}$. Stevenson asked the British government to explain its statement as to the recognition of the slaves of the Comet and Encomium and refusal in the case of the Enterprise ${ }^{37}$. After a period of consideration, the British government still did not change their view of the case of the Enterprise because it was unfounded in their opinion $^{38}$. The matter of the Enterprise continued to be a subject of controversy in British-American relations ${ }^{39}$. Specifically for the Comet and the Encomium, the American government expressed its desire to conduct negotiations and reach an agreement with Great Britain to resolve the slavery related issues that occurred in 1831 and 1834 satisfactorily $^{40}$. With consideration to the United States, Palmerston claimed that he would make sure Stevenson's proposed agreement between the two countries would soon be considered by the British government ${ }^{41}$. After considering the proposal

${ }^{35}$ See A Dispatch from Lord Viscount Palmerston to Stevenson, January $7^{\text {th }}, 1837$, [in:] ibidem, pp. 15-16.

${ }^{36}$ See Letter of Stevenson to Lord Palmerston, January 14 $4^{\text {th }}$, 1837, [in:] ibidem, p. 16.

37 Stevenson in the dispatch asked Palmerston to pay more attention to the United States government's claim concerning shipwrecks in the Bahamas and the freeing by British colonial authorities. The United States believed that the rejection of the Enterprise's claim not only went against public law and the rights of United States citizens but also against the respect of foreign powers to the constitution of an independent and friendly country. Since then Stevenson asked Great Britain not only to reconsider but to abandon it in the case of the Enterprise. For compensation for the loss of slaves of the Comet and the Encomium, compensation adjustment would be carried out along with evidence, and it had to be done quickly and without delay. See Letter from Stevenson to Lord Palmerston, May $12^{\text {th }}$, 1837, [in:] ibidem, pp. 17-24.

${ }^{3}$ Due to the reaction of the American side related to the case of the Enterprise, Great Britain expressed its concession when arguing that it was only a difference in the views of the two governments and hoped to continue discussions to find a unified solution for the case of Enterprise. See Letter from Lord Palmerston to Stevenson, December $11^{\text {th }}, 1837$, [in:] ibidem, pp. 25-28.

39 See Letter from Stevenson to Lord Palmerston, December 23 ${ }^{\text {rd }}$, 1837, [in:] ibidem, pp. 28-35.

${ }^{40}$ See Letter from Stevenson to Lord Palmerston, April 17th 1838 , [in:] ibidem, pp. 35-36; Extract of a letter from Stevenson to Forsyth, April 21 ${ }^{\text {st }}$, 1838, [in:] ibidem, p. 35.

${ }^{41}$ See Letter from Palmerston to Stevenson, April 28 th, 1838 , [in:] ibidem, p. 37. 
by the United States, the British government said that it was too early to come to an agreement at the conference. What was needed at the time was that the United States point out to Great Britain the issues that would be discussed by the two countries before signing these agreements ${ }^{42}$.

In September 1838, the two countries began discussing specific issues related to the compensation for the lost slaves of the Comet and the Encomium. However, the views of the two countries differed in how to calculate the value of the slaves of each ship. The United States proposed that there were 165 slaves on board the Comet; their average value was estimated at 600 Spanish dollars per person. On the Encomium there were 45 slaves. The total estimated slave value was 34,575 Spanish dollars ${ }^{43}$. This amount included the interest which had been calculated at $6 \%$ per year from the time of seizure to the time of payment, the total cost incurred by the owners of these slaves and their companies as a result of the seizure of the two ships. However, Great Britain countered that the number of slaves raised by Stevenson was inaccurate ${ }^{44}$. The number of slaves to be compensated for according to the British government's view was 153 from the Comet and 35 from the Encomium. Therefore, the British government did not approve of this proposal

${ }^{42}$ See Letter from Palmerston to Stevenson, May 19 $19^{\text {th }}, 1838$, [in:] ibidem, pp. 3738; Letter from Stevenson to Forsyth, July $4^{\text {th }}$, 1838, [in:] ibidem, p. 38; Letter from Stevenson to Lord Viscount Palmerston, July 10 th , 1838, [in:] ibidem, p. 39.

43 The Spanish dollar was first minted by the Spanish empire in 1497 after the currency reform and United States mint act in 1857 (the Coinage Act) was used. The Spanish dollar was commonly used in trade in Europe, America and the Far East as the first international currency. Many currencies of countries such as US dollar, Canadian dollar, Peso, Japanese Yen were originally based on the Spanish dollar. See S. Pond, The Spanish Dollar: The World's Most Famous Silver Coin, "Bulletin of the Business Historical Society" 1941, vol. XV, No. 1, pp. 12-16.

${ }^{44}$ According to the British government, the above number of slaves on the Comet and Encomium stated by Stevenson was from the time the ship began its voyage until the sinking in the Bahamas. In fact, in reports received by the British government from the colony, at the time of the seizure, 11 slaves on the Comet escaped from the ship, escaped from the detention of the slave owners before others and the ship were seized by customs officers. At the same time, the report also pointed out that 11 other people including 1 slave from the Comet and 10 slaves from the Encomium returned to the United States with their owners. Therefore, these 22 slaves would be deducted from the number proposed for compensation. See Letter from Lord Palmerston to Stevenson, September 13 ${ }^{\text {th }}, 1838$, [in:] Message from the President of the United States, in compliance..., pp. 40-41. 
and suggested some ideas for recalculation ${ }^{45}$. Great Britain also refused the offer of a $6 \%$ interest rate each year to pay for the costs incurred by the slave owners in relation to initiating a petition to claim compensation for the lost slaves. However, Great Britain would consider a certain amount of compensation for the delay in dealing with the slave owners' claims. The evidence provided by the United States would be checked and Great Britain would notify the United States representative of the time for an agreement between the two parties ${ }^{46}$.

After inconsistent arguments, in December 1838, in a letter sent to Palmerston, Stevenson re-evaluated the results of the discussions between the two governments about compensation for the cases of the Comet and the Encomium. Subsequently, Stevenson pointed out the inconsistent issues between the two countries including the number of slaves compensated for, the value of the slaves and the total amount of compensation. Regarding the number of slaves proposed for compensation, the United States gave concrete evidence and arguments which they relied on to recommend the slaves' value. The United States relied on reports, statements and testimonies that gave 6 pieces of evidence to confirm the number of slaves on the Comet that were released by the British colonial government ${ }^{47}$. In the case of the Encomium, the United

45 According to the British government's point of view, Stevenson only referred to the exact value of the slaves at the time of the ship's wreck. In fact, the exact value of the slaves can only be achieved if the ship could reach the port of New Orleans and the slaves were in a healthy state. Therefore, the calculation in the proposal given by Stevenson also included the profit of this adventurousness. Great Britain expressed some ideas about calculating the value of the slaves that Great Britain had to compensate. Great Britain said that the slave owners needed to have their proposal for compensation for the extent of the damage caused by their slaves being seized and released by the British colonial government. However, the slave owners had to consider the difficulties they face, even if they succeeded in moving the slaves to another ship and leaving the port of Nassau, they had to take into account all the risks and expenses for their voyage to New Orleans. See Letter from Lord Palmerston to Stevenson, September $13^{\text {th }}, 1838 \ldots$, pp. $40-41$.

${ }^{46}$ Ibidem, pp. 41-42.

47 The calculation of the slaves' value in the United States was based on the following grounds: Firstly, the original testimony of the Comet captain on January $20^{\text {th }}, 1831$. This testimony confirmed that the number of slaves on the Comet was 165. That was also the number of slaves under the control of the colonial government. Although 11 slaves escaped from the ship, these people were seized and returned to the ship afterwards. All slaves were under government control 
States said that, based on the captain's testimony, the passengers clearly indicated that the slaves were all seized by the British government $^{48}$. Regarding slave valuation, the United States indicated that the valuation at New Orleans (the port of destination), which was not the valuation initially or at seizure, was presented in the dispatch dated February $8^{\text {th }}, 1838$. It was accepted by Palmerston not only in this case but also in other separate cases, as very fair and clear. Moreover, the United States argued that the slave owners were not slave traders, but owners of cotton and sugar plantations. Therefore, the liberation of slaves by Great Britain caused their loss of slaves employed in cultivation on the fertile lands of Mississippi. That led to the consequence that they not only lost profits but also suffered badly from the contracts they signed while their working vehicles, the slaves, were lost ${ }^{49}$. Regarding the interest on the total value of the slaves, the United States argued that an individual or country may be deprived by another country of the use of their property for a time. Therefore, slave owners not only made a claim for the total value of their slaves but also for the interest on this value from the time of seizure until payment ${ }^{50}$.

and released. Secondly, in the Royal Gazette newspaper on January $12^{\text {th }}, 1831$, the situation of the sinking ship and the way the ship was brought to Nassau were presented in great detail. Page 15 of the article clearly stated that 11 slaves escaped to shore on the first and second nights after the ship arrived at the port of Nassau. These people found their way to the government and were seized and handed over to the police. They were then reviewed and detained by customs officers. Thirdly, the colonial government in the letter sent to Lord Goderich, the Nassau government spokesperson on the seizure of slaves, stated that in no way could an official dispatch miss the mention of 11 slaves if they were not in the original seizure. Fourthly, the House of Assembly's report on the issue of slaves presented the circumstances of the wrecked ships, the number of slaves seized. The report clearly stated that 11 slaves who fled to the shore were later seized by the government and detained in the Nassau workhouse. Fifthly, in the official copy of the Vice Admiral's presentation at court, it was acknowledged that 165 slaves were being detained by colonial officials. Sixthly, in the colonial Governor's report at the end of March 1831, it was clearly stated that there were 165 slaves of the Comet that won the right to live in the colonies. See Letter from Lord Palmerston to Stevenson, September 13 ${ }^{\text {th }}, 1838 \ldots$, pp. 47-48.

48 The United States relied on evidence which were statements in the captain's testimony attested by the United States consul's testimony at Nassau, who actually boarded and participated in the ship's inspection. The consul confirmed that no slaves were brought back to the United States. See ibidem, p. 47.

49 See ibidem, p. 49.

50 See ibidem, pp. 54-55. 
In May 1839, the United States and Great Britain reached an agreement on compensation. Under this agreement, Great Britain would pay compensation for 146 slaves from the Comet and 33 slaves from the Encomium, bringing the total to 179 lost slaves compensated for ${ }^{51}$. The total amount of compensation was 70,000 dollars and 15,739 dollars for the Comet and the Encomium respectively $^{52}$. The two parties agreed to an interest rate of $4 \%$ per year from the time the ship was seized by customs officers at the Bahamas until Great Britain paid the amount of compensation for the release of the slaves. In total, the British government had to compensate 11,617,962 dollars including the interest and the cost of freeing the slaves for the two cases of the Comet and the Encomium $^{53}$. However, Southern governors were not satisfied with the compensation, especially John C. Calhoun ${ }^{54}$. The internal atmo-

51 The agreement determined that when the ship was wrecked, 164 slaves on the Comet were safe to be taken to port in Nassau. However, 11 people escaped from the slave owners by swimming to the shore when the ship arrived in Nassau, 5 of the slaves returned to servant status in the United States and two died. Therefore, only 146 people were compensated. When the Encomium ship was wrecked, 45 slaves were safe, but 12 of them together with their owner returned to the United States. Therefore, only 33 slaves were proposed for compensation. See Treasury Minute, April 1839 on the Compensation to be granted in the cases of the United States vessels "Comet", "Encomium" and "Enterprise" for Slaves landed on British Territory, [in:] Parliamentary Papers, vol. XXVIII, published by H.M. Stationery Office, 1842, pp. 230-231.

52 In the case of the Encomium, 13 slaves were compensated for with 6,200 dollars and theyreceived 9,539 dollars in compensation for the remaining 20 slaves. Therefore, in total, 15,739 dollars were given to the case of Encomium. See Treasury Minute, April 1839 on the Compensation..., p. 231.

53 The British Foreign Secretary paid $80 \%$ of this total to insurance companies that paid the slaves owners who bought insurance. In 1842, the British Foreign Secretary - Forsyth transferred the rest of the amount to the United States at about 7,695 dollars. See J.B. Moore, op. cit., p. 353.

${ }^{54}$ After the compensation agreement between the two countries, John C. Calhoun of South Carolina reprimanded Buren for his too gentle attitude to claiming Palmerston compensation the slave owners. Calhoun had created a struggle in the United States Congress against British action regarding this issue. In March 1840, Calhoun submitted to the United States Congress a number of solutions to confirm the rights of slave owners under international law. Calhoun said that, according to a law of nations, a ship at sea, during peace time that made a legitimate voyage, according to the laws of the nations and that if the ship was forced by bad weather or other inevitable circumstances to enter into the port of a friendly power, in that case, that nation would not lose any rights at sea or personal relations of those on board. This solution was adopted by Congress. See Opinion of 
sphere of the United States government became even more stressful when no formal solution was found and the above cases had not been resolved. Then the Hermosa ship incident occurred.

On October $19^{\text {th }}, 1840$, under the command of Captain John Chattin, the Hermosa was wrecked on Abaco Island. The ship was making its voyage from Richmond to New Orleans with 47 slaves on board ${ }^{55}$. The Hermosa's captain asked the head of the rescue ship to take them to any port in the United States. However, the rescuer refused and took the ship to Nassau. On October $22^{\text {nd }}$, 1840, the ship arrived in Nassau. Once there, the captain did not allow the slaves to go ashore or have any contact with people on the shore. At the same time, he let the ship anchor at port and kept away from the wharf. During the time at port, the Hermosa's captain went to see John Bacon, United States Consul at Nassau. He wanted the help of Bacon to find another ship to bring all crew, passengers and slaves to a port in New York. Meanwhile the Hermosa government and its forces, consisting of judges with the support of British West Indian soldiers, boarded with muskets and bayonets, seized the ship and took the slaves ashore. All of the slaves on board were taken to a judge's office in Hermosa. Trial procedures were conducted and they were released ${ }^{56}$.

In the United States, while the case of the Hermosa was happening, Alexander Barrow presented a request from insurance companies from his state wishing for Congress to provide solutions to obtain compensation from the British government for the loss of slaves. Barrow strongly asserted that this case may be a matter of war or peace with Great Britain ${ }^{57}$. On May $3^{\text {rd }}$, 1842, Edward Everett - the United States Secretary of State sent a letter to Lord Aberdeen, the British Secretary of Foreign Affairs. In the letter

Mr. Upham, United States Commissioner, in the case of the Enterprise, [in:] Reports of International Arbitral Awards, vol. XXIX, New York 2012, p. 29.

${ }^{55}$ See J.P. Rodriguez, Slavery in the United States: A Social, Political, and Historical Encyclopaedia, vol. I, California 2007, p. 336.

56 See Report of decisions of the commission of claims under the convention of February 8, 1853, between the United States and Great Britain, transmitted to the senate by the president of the United States, August 11, 1856, Washington 1856, p. 239.

57 Borrow stated that, if the British government continued to intervene with their trade, their navy would sink them. Barron's views received the support of Calhoun and other Senators. They sent a diplomatic dispatch to the Commission on foreign affairs but were advised by the parties to wait for British action to the Creole case. See J.R. Giddings, op. cit., pp. 175-176. 
Everett pointed out that the direct intervention of the British government in Nassau established freedom for slaves. Everett asked the British government to pay compensation for the losses suffered by the former slave owners ${ }^{58}$. However, the Hermosa case also fell into the same stalemate as in the case of the Enterprise ${ }^{59}$.

In general, all four incidents involving the United States slave ships at sea had many similarities. All of the slaves wanted to be liberated and were facilitated by the local government in acquiring their freedom. In the first two cases, the British government subsequently compensated the American slave owners for its illegal seizure and release of slaves from the American ships by the British colonial government. At that time, colonial slavery was still active in their territories. In the latter two cases, American slave owners did not receive any amount of compensation because Great Britain had abolished slavery in the colonies. Any slave on British land or in the British maritime border was legally free due to the abolition of slavery in $1833^{60}$. These cases continued to be debated by both parties, especially since the occurrence of the Creole in $1841^{61}$ which was the largest case in British-American relations which involved the abolition of slavery and maritime rights ${ }^{62}$.

58 See Letter from Everett to Lord Aberdeen, May 3, 1842, [in:] British and Foreign State Papers, 1842-1843, vol. XXXI, London 1858, pp. 705-708.

59 Aberdeen soon countered Everett's claim, saying that Everett relied on the two statements by the Hermosa captain before the United States inspection. But these statements had some differences compared to the Hermosa captain's testimony received by the British government from the Governor of the Bahamas. As for the United States government's compensation claim, Aberdeen said that, Everett pointed out under the law dated August $28^{\text {th }}$, 1833 on the abolition of slavery and British slave owners would receive an amount of compensation. Aberdeen said that this issue was discussed between the two parties on December $11^{\text {th }}$, 1837 in the case of Enterprise. Aberdeen once again confirmed Palmerston's earlier statement, currently slavery had been abolished on the entire British Empire. There was no basis for the claim of foreign ships for slavery-related compensation under any circumstances, which may enter British colonies, or enter Great Britain. See Letter from Lord Aberdeen to Everett, May 20, 1842, [in:] ibidem, pp. 709-711.

60 J.R. Kerr-Ritchie, op. cit., p. 126.

${ }^{61}$ See T.A. U pchurch, Abolition Movement, California 2011, p. 48.

${ }^{62}$ An Act to Prohibit the Importation of Slaves into any port or place within the jurisdiction of the United States: From and after the first day of January, in the year of our Lord one thousand eight hundred and eight, http://avalon.law.yale.edu/ 19th_century/s1004.asp (online: 21 VI 2018); W. Johnson, White lies: Human property and domestic slavery aboard the slave ship Creole, "Atlantic Studies" 2008, vol. V, No. 2, p. 239. 
The Creole was also an American slave vessel departing from Virginia on October $27^{\text {th }}, 1841$, and bound for New Orleans under the command of Captain Robert Ensor ${ }^{63}$. The ship was transporting 135 slaves $^{64}, 10$ crew members, 8 black servants, and 4 passengers ${ }^{65}$. The Creole made the journey as usual and everything remained quiet until the evening of November $7^{\text {th }}, 1841^{66}$, when Madison Washington, the leader of the slaves, and 18 other men rebelled $^{67}$. They overwhelmed the crew, killed John Hewell and took control of the ship ${ }^{68}$.

${ }^{63}$ See Correspondence the Slave Trade with Foreign Powers, published by W. Clowes and Sons, London 1842, p. 147.

${ }^{64}$ Initially the Creole left Richmond with 103 slaves, and then picked up another 32 slaves in Hampton Roads, Virginia. Like domestic voyages, slaves were held on the deck. In the evening, they were limited to the underside of the ship, divided into two areas: the men in front and the women in the back. The two groups were separated by large boxes of manufactured tobacco to prevent possible exchange, which could be a risk to the interests of slave owners. Only Lewis, a longtime man servant of McCargo and six female servants were allowed to remain in the cabin. See D.E. J ervey, H.C. Huber, The Creole Affair, "The Journal of Negro History" 1980, vol. LXV, No. 3, p. 197; The Creole Case (1841), http://www.blackpast.org/ gah/creole-case-1841 (online: 21 VI 2018).

65 The crew consisted of 10 people. The commander was Robert Ensor - the captain, Zephaniah C. Gifford - the first mate and Lucius Stevens - the second mate. Members of the crew included Blinn Curtis, William Devereux, Francis Foxwell, Jacques Lacombe, Jacob Leitener, John Silvy, Henry Sperk. Four passengers include William Henry Merritt, John R. Hewell, Thomas McCargo, Theophilus J. D. McCargo, Jacob Leitner. In addition, there were also several family members of the crew on board, namely Ensor's wife and daughter, McCargo's niece and nephew. See A. Rupprecht, "All We Have Done, We Have Done for Freedom": The Creole Slave-Ship Revolt (1841) and the Revolutionary Atlantic, "International Review of Social History" 2013, vol. LVIII, p. 255; T.A. D ow n ey, The Creole Affair: The Slave Rebellion that Led the United States and Great Britain to the Brink of War, Maryland 2014, pp. 7-9.

${ }^{66}$ At this time, the Creole was about 200 miles north of Miami, about 130 miles from the southernmost point of Abaco Island in the northwest of the Bahamas, a British colony. See T.A. Downey, op. cit., p. 138.

67 The leaders of the slave revolt included Madison Washington, Ben Johnstone or Blacksmith, Elija Morris, Doctor Ruftin, George Grandy, Richard Butler, Phil Jones, Robert Lumpkins or Lumpley, Peter Smallwood, Warner Smith, Walter Brown, Adam Carney, Horace Beverley, America, Addison Tyler, William Jenkins, Pompey Garrison, George Basden, George Portlock. See Correspondence the Slave Trade..., p. 144.

68 The people who were thought to be involved in Hewell's death included Elijah Morris, Ruftin, Madison Washington, Peter Smallwood, and Addison Tyler. See ibidem, p. 137. 
When the ship was finally under control, the slaves ordered William Merritt to command the ship. Merritt and the leader of the revolt discussed the next destination together ${ }^{69}$. First, Washington wanted to take the ship to Liberia, which was established by the United States as a free colony in West Africa ${ }^{70}$. However, Merritt said the voyage was impossible because they did not have enough food and water. Ben Blacksmith, another leader of the slaves suggested that the ship be sailed to the British West Indies because he knew that the slaves from the Hermosa ${ }^{71}$ had been freed there the previous year ${ }^{72}$. Washington ordered Gifford to take the ship to Abaco or else the crew would be thrown into the sea ${ }^{73}$. Meanwhile, Merritt suggested to Washington that they go to the British port in Nassau Bahamas, where they would gain their freedom ${ }^{74}$. After further discussion, they decided to let Merritt take the ship to Nassau.

On November $9^{\text {th }}, 1841$, the Creole arrived in Nassau. Madison Washington ordered that all weapons be thrown overboard before entering the port. With this decision, the mutineers had placed themselves in the tolerance of the British government ${ }^{75}$. As the ship arrived ashore, Gifford, the first mate captain was

69 The people who participated with Madison Washington on the night of November 7, 1841 to discuss the next destination included Doctor Ruftin and George Grandy, Peter Smallwood, Warner Smith, Walter Brown, Adam Carney, Horace Beverley, William Jenkins. See ibidem, p. 147.

${ }^{70}$ Liberia was a Negro republic located on the west coast of Africa between Sierra Leone of Britain and the Ivory Coast of France. The area was about 40,000 square miles and the population was about 2,000,000. See T.J. Ad a m, Dictionary of American History, New York 1940, pp. 270-271.

${ }^{71}$ The Hermosa was an incident related to the liberation of 38 American slaves by Great Britain in 1840. See P.R. Rodriguez, The Historical Encyclopedia of World Slavery, vol. I, California 1911, p. 340.

${ }^{72}$ See Correspondence the Slave Trade..., p. 154; D.E. Jervey, H.C. Huber, op. cit., p. 200.

73 See Correspondence the Slave Trade..., p. 149.

${ }^{74}$ Nassau Bahamas was one of the places in which Christopher Columbus set foot in 1492. The Nassau Bahamas was officially founded in 1670 by a British nobleman named Charles Town. In 1695, it was renamed Nassau. See F.D. Marley, Historic Cities of the Americas: An Illustrated Encyclopaedia, vol. I (The Caribbean, Mexico, and Central America), California 2005, pp. 3-16.

${ }^{75}$ Slaves on board the Creole hoped that they would gain freedom in the British colony, except for 19 mutineers who worried that they might be thrown into jail, or worse, they would be returned to the United States. See T.A. D ow ney, op. cit., p. 15; H. Jon es, A.D. Rakestraw, Prologue to Manifest Destiny: Anglo-American Relations in the 1840s, Delaware 1997, p. 86. 
asked to dock as soon as possible and inform American Consul, John Bacon about what had happened ${ }^{76}$. Bacon agreed to get the wounded ashore and asked the governor of the Bahamas, Francis Cockburn ${ }^{77}$ to guard the Creole in order to prevent the escape of the men related to Hewell's death ${ }^{78}$. Cockburn expressed doubt over his authority to interfere in everything. However, in this situation, he would fulfil the requirements after having a discussion with Gifford and receiving a formal request from the American consul ${ }^{79}$. Cockburn ordered 24 black soldiers, commanded by a British officer, to protect the ship. Meanwhile, the council at Nassau held a special meeting and after a discussion, declared that the court was not competent enough regarding the mutineers and that the matter would be referred to the British Minister in Washington ${ }^{80}$. Cockburn asked for Bacon's opinion of the decision and received Bacon's satisfaction.

Shortly thereafter, the governor of the Bahamas sent two inspectors aboard the Creole to investigate with Bacon present as well. The investigation took place on November $10^{\text {th }}$ and $11^{\text {th }}$. However, on November $12^{\text {th }}$, after attending the meeting of the Bahamas council, Bacon worried that the British government would apply a ban on slavery to slaves of the Creole. Therefore, Bacon had developed a secret plan to regain control of the ship ${ }^{81}$. Bacon intended to steer the ship out of British authority with the slaves still on board. However, the plan failed ${ }^{82}$.

${ }^{76}$ See Correspondence the Slave Trade..., p. 135.

77 See Francis Cockburn, http://www.biographi.ca/en/bio/cockburn_francis_ 9E.html (online: 21 VI 2018); Sir Francis Cockburn (1780-1868) - Canada, Belize, Bahamas and Dover, https://doverhistorian.com/2017/02/11/sir-francis-cockburn-canada-belize-bahamas-and-dover/ (online: 21 VI 2018).

${ }^{78}$ See Correspondence the Slave Trade..., p. 127.

79 Ibidem.

80 Three issues reported by the Governor of the Bahamas to Bacon included: The Bahamas court did not have sufficient jurisdiction over alleged criminals at sea; all the Creole mutineers would be detained in Nassau until a decision was made by the Minister of Foreign Affairs whether or not to transfer them to the United States; all those who are not involved in the revolt would be free. See Correspondence the Slave Trade..., pp. 126-127.

${ }^{81}$ On November $12^{\text {th }}, 1841$, Bacon was asked to join the Bahamas council. At the meeting, Bacon was informed that the council had directed a prosecuting attorney along with a provost marshal and police along with the military ashore on board. See T.A. Downey, op. cit., p. 43.

82 Captain William Woodside of the Louisa boarded the Creole with Bacon. Here they agreed that Woodside with the four crew members of the Congress ship 
After being examined by the court, on November $13^{\text {th }}, 1841$, the attorney for the Bahamas boarded the ship and claimed that the slaves aboard were free, except for the 19 slaves who were related to the revolt and Hewell's death ${ }^{83}$. The prisoners were taken to Nassau prison. After the slaves were detained, the issue which became a subject of debate between the American consul and the British colonial authority was whether the 19 slaves were to be brought to trial in Nassau, sent to the United States for trial or brought to Jamaica. Finally, it was decided that the Creole was to be taken to New Orleans. On November $19^{\text {th }}, 1841$, the Creole departed Nassau and arrived in New Orleans on December $2^{\text {nd84 }}$.

More than a month after the incident occurred, news of the Creole had not reached Washington, D.C. yet ${ }^{85}$. When the news

would board the Creole with weapons. They together with the crew would rescue the Creole from the British officers then drive it to the Indian Key, about 400 miles from Nassau where an American warship was docked and then sail it to New Orleans. Eventually, they would bring 19 slaves related to the case to the United States for trial. A group of American sailors approached the ship on November 12, intending to steer the ship to Indian Key. The plan failed because a black soldier on board saw them and warned the British officer on the Creole. 24 soldiers with guns and bayonets were ready to fight against the ship of Captain William Woodside. Woodside was forced to leave the Creole. In protest, Gifford and his crew blamed the failure for the intervention of the British colonial authority in Nassau. See Correspondence the Slave Trade..., pp. 157-158.

${ }^{83}$ In fact, most of the slaves who were allowed to be free left the Creole except for five slaves (three women, one boy and one girl). See Correspondence the Slave Trade..., pp. 129-132, 156.

${ }^{84}$ Before the Bahamas attorney general boarded the ship, American consul and Captain of the Creole spoke to the governor of the Bahamas. The American consul expressed his desire to bring a United States warship from Indian Key to protect people and cargo on the Creole vessel from Nassau to New Orleans and a person to guard during that time. However, this request was denied. The consul continued to make a proposal to allow the crews of American ships at Nassau port to board the ship and take it to New Orleans. He also asked for a guard on board until the American sailors took over the ship, but this request was also rejected. Bacon finally suggested that American sailors on American ships at the port would board the Creole and be armed by Governor Nassau for the purpose of protecting the ship and cargo to New Orleans. However, this request continued to be rejected. See Correspondence the Slave Trade..., p. 128.

${ }^{85}$ In fact, at the second session of the $27^{\text {th }}$ Congress on December $6^{\text {th }}, 1841$ and in presidential traditional message of John Tyler one day later, the Creole case was not mentioned. In the message, relations with Britain occupied a dominant position. Tyler emphasized unresolved issues with Britain such as McLeod, Caroline and the right of visit. See Abridgment of the Debates of Congress, from 1789 to 1856: From 1789 to 1856, ed. by H.T. Benton, New York 1850, pp. 368-376. 
of the Creole arrived, the South immediately reacted strongly to British intervention in the maritime affairs of the United States and requested compensation for the slaves. Southern slave owners were angry because the British government not only violated the property rights of American slave owners but also encouraged a slave revolt ${ }^{86}$. They feared that the remaining slaves in the South would be affected by the Creole and have the idea that they would be free only when reaching British land ${ }^{87}$. Even in New Orleans, there was an explosive atmosphere about the Creole. A formal protest by Gifford and his crew for details of the event related to the situation in Nassau was sent to the American government with testimony from the $\mathrm{crew}^{88}$.

William Channing ${ }^{89}$ feared that the Creole would stir up the anger of the South, which might lead to a retaliatory attack, as well as the opportunity for Britain to implement the policy of abolition they were pursuing ${ }^{90}$. The South worried that British influence could encourage slave revolts and harm domestic slave trade at sea ${ }^{91}$. In response to the Creole, Alexander Barrow said that the Creole was very important to peace or war in Anglo-American relations. Other senators such as William R. King ${ }^{92}$, William Preston ${ }^{93}$

${ }^{86}$ E.B. Rugemer, Slave Rebels and Abolitionists: The Black Atlantic and the Coming of the Civil War, "The Journal of the Civil War Era” 2012, vol. II, p. 192.

${ }^{87}$ See T.A. Downey, op. cit., p. 43.

${ }^{88}$ Under maritime law, an appeal, about the ship's damage on the voyage by storm or other factors, shall be written by a captain and must be authenticated by a judicial officer or a notary. The protest of the first mate Captain Gifford (since Captain Ensor was severely wounded in Nassau) was witnessed by Merritt, Cargo and authenticated by Leidner. See Correspondence the Slave Trade..., pp. 151-159.

89 William Ellery Channing (1780-1842) was an American theologian born in Rhode Island. He was the author of The Duty of the Free States; or Remarks Suggested by the Case of the Creole regarding the Creole affair. See William Ellery Channing, https://www.britannica.com/biography/William-Ellery-Channing (online: 21 VI 2018); William Ellery Channing, https://theodora.com/encyclopedia/c/william_ellery_channing.html (online: 21 VI 2018).

${ }^{90}$ D. Hicks, Dr. Channing and the Creole Case, "The American Historical Review" 1932, vol. XXXVII, p. 517.

${ }^{91}$ H. Jones, A.D. Rakestraw, op. cit., p. 36.

${ }^{92}$ William R. King (1786-1853) was a politician, diplomat, US senator from Alabama and $13^{\text {th }}$ Vice President of the United States. See William Rufus King, $13^{\text {th }}$ Vice President (1853), https://www.senate.gov/artandhistory/history/common/generic/VP_William_R_King.htm (online: 12 VI 2018).

${ }_{93}$ William Preston (1816-1887) served in the House of Representatives (18301832, 1844-1845), the Senate of Virginia (1840-1844), the United States House of Representatives (1847-1849) and the Federal Senate (1862) Head of the Navy 
and William Cabell Rives ${ }^{94}$ agreed with Barrow's view that a war between the two nations was not far off. Among the Southern Senators, John C. Calhoun was one of the people with the strongest opinion $^{95}$. On January $10^{\text {th }}, 1842$, Calhoun introduced a solution to the case of the Creole in Congress and his solution was accepted. However, on January $18^{\text {th }}, 1842$, Webster sent a report to the President explaining that neither the owners of the slaves nor the insurer had requested the Ministry of Foreign Affairs' assistance. Webster announced that he would send a letter to Everett, the Secretary of the United States in London.

On January $29^{\text {th }}, 1842$, Webster wrote a letter to Everett, the US Minister in London, expressing his views on the Creole ${ }^{96}$. Webster said that this issue seriously threatened peace between the two countries. According to him, the fact that the Creole was making the trip from one port to another port in the United States and that the ownership of slaves aboard was legal and recognized by the United States Constitution. Webster asserted that the British authority in Nassau should have been responsible for assisting the American consulate in returning the ship and cargo to their owners. The property of individuals should not be subject to national law if it is brought into the territorial sea by force and rebellion ${ }^{97}$. This view was confirmed by Everett towards Aberdeen in London ${ }^{98}$.

(1849-1850). See William Preston, https://www.encyclopediavirginia.org/media player?mets_filename=evm00002634mets.xml (online: 21 VI 2018).

94 William Cabell Rives (1793-1868) was a United States Senator from Virginia (1841-1845), Secretary of the United States in France (1849-1853), who supported the abolition of slavery. See E.M. Th o m a s, William Cabell Rives and the British Abolitionists, "The Virginia Magazine of History and Biography" 1981, vol. LXXXIX, No. 1, pp. 64-66.

${ }^{95}$ John Caldwell Calhoun (1782-1850) was an American politician. He had held many important positions such as Secretary of War, Secretary of State, Vice President of the United States. See A. Bartnicki, K. Michałek, I. Rus inowa, Encyklopedia historii Stanów Zjednoczonych Ameryki lod Deklaracji Niepodległości do współczesności), Warsaw 1992, pp. 44-45.

96 See The Creole Case and Mr. Webster's Dispatch: With the Comments of the N.Y. American, ed. by W. Jay, New York 1842, pp. 4-11.

97 Correspondence the Slave Trade..., pp. 115-123.

98 Everett said that cases such as the Comet, the Encomium, the Enterprise and the Hermosa and the slaves aboard were liberated by the British. In similar cases to the Creole, the United States government took a part of the slaves of traders, claiming compensation from the British government for liberating the property of the traders - as an implicit apology for British intervention in the internal affairs of the United States. See ibidem. 
In Congress, this issue had become a subject of serious debate among abolitionists. On March $21^{\text {st }}$ and $22^{\text {nd }}, 1842$, Joshua R. Giddings proposed nine solutions to encourage slave freedom and the Creole $^{99}$. Giddings said that the United States consulate in Nassau should stop pressuring the Bahamas and that Webster should stop punishing the British government for the incident ${ }^{100}$. The House of Representatives had censured Giddings with a 126-69 vote $^{101}$, in which all of the Democrats and most of the Whigs voted against Giddings ${ }^{102}$. After that, on March $26^{\text {th }}$, Channing published an essay titled "The Duty of Free States or Remarks Suggested by the case of the Creole"103. Channing said that although a rebellion might occur on a voyage, one country's local laws were not applicable in another locality. The essay immediately spread and received the support of Southern leaders like Charles Sumner ${ }^{104}$ and Joshua Giddings ${ }^{105}$.

${ }^{99}$ Of the 9 solutions proposed by Giddings, only 3 solutions had proposed principles that applied directly to the Creole. Giddings said that when the Creole had left Virginia, the slavery laws of Virginia had been suspended for the people on board and they had to obey the laws of the United States. Explaining the rebellion of 19 slaves, Giddings said it was only a restoration of personal freedom and did not violate the United States' laws and was not responsible for the punishment. Giddings pointed out the state of slavery, its application to international laws, and that the government's attempt to re-establish slavery was not consistent with the honour of the United States. See P.J. Rodriguez, Slavery in the United States..., pp. 317-318; S.W. Savage, The Origin of the Giddings Resolutions, "Ohio Archaeological and Historical Quarterly" 1936, vol. XLVI, pp. 28-39.

100 See T.A. Downey, op. cit., p. 137.

101 Censure was the official voting form of censure by the majority of members when a member of parliament did something wrong. To remove the membership of that person required two thirds of the votes of the members of the parliament. See Censure, http://www.oxfordreference.com/view/10.1093/acref/ 9780195142730.001.0001/acref-9780195142730 (online: 21 VI.2018).

102 Joshua R. Giddings was a Whig party member from Ohio. After being rejected by the House of Representatives, Giddings resigned from Congress to protest. On May $5^{\text {th }}, 1842$, more than 7,469 voters backed Giddings back to his place in a special election. See B.R. Morris, Encyclopedia of American History, New York 1982, pp. 220-221; P.R. Ludlu m, Joshua R. Giddings, Radical, "The Mississippi Valley Historical Review" 1936, vol. XXIII, No. 1, pp. 49-60.

103 See E.W. Channing, The Duty of the Free States; or Remarks Suggested by the Case of the Creole, London 1842.

104 Charles Sumner (1811-1874) was an Amercing politician, a United States Senator from Massachusetts. He was the leader of the fight against slavery in Massachusetts. See Charles Sumner, https: / /www.history.com/topics / 19th-century/ charles-sumner (online: 21 VI 2018).

105 D. Hicks, op. cit., pp. 523-525. 
While the American public reacted very strongly to the case of the Creole, the British government received the information very late. By mid-December, news of the Creole arrived in London. However, only a few days later, the incident of warships sinking in Nassau made the British government more anxious. In fact, relations between the two countries had been tense for decades and the Creole could further the risk of war. In this situation, Aberdeen, Secretary of State for Foreign Affairs, announced to Everett, the United States Minister in London, Ashburton's special mission. Everett then quickly informed Webster of Ashburton's mission. Although the news arrived in London, it was not until January $28^{\text {th }}$, 1842, that British Ambassador to the United States, Henry $\mathrm{S}$. Fox, sent a report on the Creole to Aberdeen. In the letter, Fox expressed the view that the US government had no right to request any compensation from Great Britain for the case of fleeing slaves. Fox cited cases similar to the Creole ${ }^{106}$ And, in particular, Fox claimed that the testimony of the Creole crew of the incident was inaccurate. Fox denied the responsibility of the British government and considered it the responsibility of the insurer involved in the loss of slaves of American owners in Nassau ${ }^{107}$. Therefore, the British government did not pay proper attention to the Creole. Ashburton regretted the Creole incident, but the British warmly welcomed Peel's policy against slavery and so there would be no compensation for slaves freed from the ship ${ }^{108}$. He did not recognize any laws of the United States on punishing slaves. British law recognized mutineers as objects, human beings who could act rather than property ${ }^{109}$. Neither Aberdeen nor Ashburton had been prepared for this ${ }^{110}$. In fact, on February $8^{\text {th }}, 1842$, Aberdeen gave Ashburton instructions as the official guide towards

106 Earlier, the United States and Great Britain also experienced the incidents related to slave ships entering British colonies. Under Britain's slave-abolition policy, since 1834 all foreign slave ships entering Bermuda and the Bahamas would be confiscated from slaves and property without compensation. Slave ships such as the Comet, the Hermosa and the Enterprise went into the British colonies, so the confiscation of slaves initiated booming events between the two countries on the issue. See Correspondence the Slave Trade..., p. 112.

107 Ibidem, p. 160.

108 D.W. J o ne s, op. cit., pp. 42-43.

109 M.M. Sale, The Slumbering Volcano: American Slave Ship Revolts and the Production of Rebellious Masculinity, Durham-London 1997, p. 143.

110 Correspondence the Slave Trade..., p. 153. 
the talks prior to coming to the United States. However, the Creole affair was not mentioned ${ }^{111}$.

By early 1842, the connection between the United States and Great Britain became fragile. The British government wanted to improve relations with the United States, so it was a good idea to start with a fair approach to small issues ${ }^{112}$. In response to issues arising in bilateral relations, Ashburton arrived in Washington, D.C. on April $4^{\text {th }}, 1842$. However, at this time, Dorr's rebellion in Rhode Island caused distress for both Tyler and Webster ${ }^{113}$. When some issues were resolved, both Webster and Ashburton quickly participated in informal discussions on a range of issues ${ }^{114}$. Although the Creole was not mentioned in the instructions, due to public agitation on the matter Ashburton felt that it was necessary to take the issue into consideration ${ }^{115}$.

Regarding the tension between the two sides, the British government eased the situation by offering a promise that any slaves

111 Aberdeen pointed out Ashburton's mission to the United States. It was to address issues such as the Northeast Frontier, the Oregon border, the Northwest Frontier, the Caroline incident and the right of search. See D. Ad ams, Lord Ashburton and the Treaty of Washington, "The American Historical Review" 1912, vol. XVII, No. 4, p. 766.

112 D.W. Jones, op. cit., p. 49.

113 The revolt was the struggle of middle-class people led by Thomas Wilson Dorr, seeking to extend the democratic rights in the Rhode States of the United States between 1841 and 1842 .

114 The negotiations between Daniel Webster and Lord Ashburton mainly focused on several problems, namely the boundary controversy in Maine and New Brunswick, the right of search, annexation of Texas, the question of Oregon, and the Caroline Affair. See H.S. Burrage, Maine in the Northeastern Boundary Controversy, Portland 1919; N.V. Sang, The Caroline Affair and the Diplomatic Crisis between Great Britain and the United States, 1837-1841, "Prawo i Polityka" 2018, No. 8, pp. 73-83; N.V. Sang, The question of Oregon in British-American relations, 1818-1846, "Koło Historii" 2017, No. 21, pp. 43-58; D. Adams, op. cit., pp. 764-782.

115 Ashburton realized that security for the future was of paramount importance to slave owners in the South rather than compensation for losses. Both Webster and Ashbuton were concerned that the Creole could interrupt other issues, even the Maine border problem. At that moment, the United States and Great Britain were in the process of negotiating border issues such as the Oregon dispute, the northeast border problem in Maine and New Brunswick, and the Texas problem. See D.W. J on es, The Influence of Slavery on the Webster-Ashburton Negotiations, "The Journal of Southern History" 1956, vol. XXII, No. 1, pp. 48-58; D. Ad a m s, op. cit., p. 766; N.V. S a ng, The British-American Diplomacy in Searching for the Northeast Boundary in Maine and New Brunswick, 1820-1846, "Annals of the University of Craiova. History" 2018, vol. II, No. 34, pp. 35-48. 
of future revolts would be returned to the United States. However, soon afterwards, Aberdeen, in a letter to Ashburton, gave no guarantee of this ${ }^{116}$. In contrast, the main point in Americans' views of the Creole focused on opposing British intervention against American ships in search of shelter and demanding the return of fleeing slaves ${ }^{117}$.

From the response of the two countries to the Creole, two issues were considered to be the cause of failure in finding a solution to this problem, namely maritime rights and criminal extradition. Webster and Ashburton all looked forward to an extradition treaty ${ }^{118}$. On April $28^{\text {th }}$, Ashburton wrote to Aberdeen to present Webster's wishes for linking the Creole to a general extradition treaty. Ashburton presented Webster's suggestion that British colonial officials should not only avoid all interference with slave ships stopping at British ports due to bad weather, but also, in the event of a slave revolt, help the owners restore ownership of their ship ${ }^{119}$. However, Aberdeen argued that the extradition treaty could lead to some difficulties in defining commitment clauses regarding liberating slaves, especially in a case on the sea, where local laws did not exist. Aberdeen said that the extradition treaty should be considered but must be submitted to the State for Foreign Affairs before it could give its views ${ }^{120}$. As far as maritime rights were concerned, Aberdeen insisted that it was impossible ${ }^{121}$.

Aberdeen's inconsistencies towards the Creole, the reaction of the United States and the uncompromising resolution of the British

${ }^{116} \mathrm{He}$ pointed out, however, that, under the influence of weather or force, slaves must be free within the sphere of British jurisdiction. Great Britain would not offer any guarantee for any future voyages and recommended the United States should probably use a guard system. See Correspondence the Slave Trade..., p. 256.

117 H.T. Gordon, The Treaty of Washington, Concluded August 9, 1842, by Daniel Webster and Lord Ashburton, Berkeley 1908, p. 213.

118 In fact, before Ashburton arrived in Washington, Webster sent a letter to a friend in Massachusetts, Joseph Story. Story advised Webster that it lacked alegal basis to return 19 slaves that were being arrested in Nassau. Webster had asked Story about the clause to come to a treaty to resolve the issue of a ship being taken to a foreign port as well as extradition. See H. Jones, To the Webster-Ashburton Treaty: A Study in Anglo-American Relations, 1783-1843, Carolina 1977, pp. 145-146.

119 D. Adams, op. cit., p. 776.

120 Ibidem.

121 The Diplomatic and Official Papers of Daniel Webster, while Secretary of State, New York 1848, p. 254. 
parliament pushed Ashburton into a dilemma during negotiations with Webster. The dilemma of the two sides was expressed by Webster in his letter to John David on April $16^{\text {th }}, 1842$. In his letter, he argued that the position of the United States on the matter of the Creole was misunderstood and incorrect ${ }^{122}$. Not receiving advice from Aberdeen after two talks and great pressure mounting from the South, Ashburton had expressed his complaints towards Aberdeen ${ }^{123}$. He said that both the President and almost all of the Senate had strong views on the Creole ${ }^{124}$. He described: "He [the president] is very sore and testy about the Creole" ${ }^{125}$. Having received no instructions from London while having to act decisively on the final days of his mission, Ashburton decided to act in his own way. Ashburton thought that, because the incident was the cause of strong reactions, involving both nations and international law, Ashburton would refer this matter to London once again. There, Ashburton hoped the two governments would connect at a meeting on an extradition treaty with a resolution on the Creole. Ashburton was also thinking of compensating for the lost slaves, but he believed the British government was unlikely to accept it ${ }^{126}$.

As a result of lengthy negotiations, the security of the Bahamas Chanel and the extradition were quite limited. It failed to reach an extradition treaty. However, Ashburton, in an official letter to the United States government, had suggested that delicate matters could best be settled in London ${ }^{127}$. Ashburton promised to limit informal interventions as American vessel attempted to seek shelter in the British port ${ }^{128}$. This promise was addressed in Ashburton's letter to Aberdeen on May 26 ${ }^{\text {th }}, 1842^{129}$. To prevent future cases like the Creole and placate to the groups that opposed slavery in the United States and Great Britain, Webster and Ashbur-

${ }^{122}$ See Correspondence the Slave Trade..., p. 241.

123 See ibidem, p. 254.

${ }^{124}$ See in the letter, Ashburton wrote: "The President, as a Virginian, has a strong opinion about the Creole case, and is not a little disposed to be obstinate on the subject". See ibidem, p. 267.

125 See ibidem, p. 261.

${ }^{126}$ H. Jones, op. cit., p. 147.

127 See The Diplomatic and Official Papers of Daniel Webster, while Secretary of State, New York 1848, pp. 83-91; W. Kaufman, S.H. Macphers o n, Britain and the Americas: Culture, Politics, and History, California 2005, p. 295.

${ }^{128}$ H. Jones, Crucible of Power: A History of American Foreign Relations to 1913, Maryland 2002, p. 130.

129 See Correspondence the Slave Trade..., pp. 717-718. 
ton, in a treaty signed on August $9^{\text {th }}, 1842,{ }^{130}$ established a clause on the mutual extradition of defectors of seven types ${ }^{131}$. This clause was opposed mainly by the British side. Opponents said that this statement would apply to all fleeing slaves ${ }^{132}$. The misunderstanding was later explained by Aberdeen.

In the United States, on August $11^{\text {th }}, 1842$, President Tyler submitted a treaty to Congress. The views of Congress's members were very different. Thomas Benton said that in practice it would be very difficult to put into effect ${ }^{133}$. However, John Calhoun expressed his support that the treaty would bring peace to the two countries and he found Ashburton's guarantee of security measures in maritime transport satisfactory. On August $20^{\text {th }}$, the Senate voted 39-9 on the contents of the treaty. This support was beyond the imagination of Webster ${ }^{134}$. By 1846, the issue of the treaty, including the Creole, continued to be debated in Congress. Webster acknowledged that, although the advantages for the United States' maritime rights had not been achieved yet, the matter of resolving the case of the Creole had been conducted with the utmost effort from his talents and morals. After the treaty was signed, the two countries also took part in a trial regarding disputes between slave owners, the Creole owners and insurers involved in the damages from the revolt ${ }^{135}$.

130 This treaty was also known as the Webster-Ashburton treaty. At first, Webster and Ashburton signed 2 treaties: one on border issues, another dealing with other issues in bilateral relations. However, the two treaties were then grouped into one, in which, seven articles were related to border issues, Articles VIII and IX were related to the establishment of common guards off the African coast, Article $\mathrm{X}$ were related to the extradition of crimes. The treaty was extended by the British and American governments twice in 1889 and 1931. See Treaties and other International Acts of the United States of America, vol. II (Documents 1-40: 1776-1818), ed. by H.D. Miller, Washington 1931, p. 82.

131 Crimes included all persons who, being charged with the crime of murder, or assault with intent to commit murder, or piracy, or arson, or robbery, or Forgery, or the utterance of forged paper. See Treaties and other International Acts..., p. 88.

132 See H.T. Gordon, op. cit., p. 232.

133 See H.T. Benton, Benton Thomas Hart: Thirty Years' View, New York 1856, p. 444.

${ }^{134}$ H.T. Gordon, op. cit., p. 217.

135 In March 1845, the New Orleans Supreme Court ruled between McCargo and the Merchants Insurance Company of New Orleans. McCargo's proposed compensation to the insurance company was 20,800 dollars. However, the court ruled that the insurance company only compensated McCargo 18,400 dollars. 
In fact, the United States and Great Britain settled the problem of the Creole on the account of the immediate interests of the two countries. The injuries involved in the liberation of slaves was not mentioned and judgment of the Creole was temporarily halted. On October $31^{\text {st }}$, 1853, the British commissioners asked Joshua Bates $^{136}$ to be the arbitrator and this proposal received the consent of the United States commissioners. On November $2^{\text {nd }}$, Bates officially accepted the proposal and two weeks later the matter was resolved. However, Bates' decision was not accepted by both parties. In 1855, Joshua Bates declared another judgment. In this judgment, Bates asserted that, although slavery was inhumane, the laws of one nation could not prevent another nation from establishing it by law. The Creole was on a legal voyage. Bates said that, when it became necessary, it was inevitable to steer the Creole to Nassau and the Creole had the right to seek shelter from a friendly nation. Regarding the slaves, the Governor of Nassau should have helped the Creole officers get them back. Bates ruled that the British Liberation Act was not applicable in this case, as no local laws allowed the armed forces to board another nation's ship. Because Nassau officials violated international law, the British government had to pay compensation to the Creole's slave owners. The British-American Claims Commission decided that the British government had to compensate the owners of the lost slaves 30,330 dollars ${ }^{137}$. The Creole dilemma ended after more than seven years of controversy between Britain and the United States. The settlement of the Creole case had an important position in British-American relations regarding slavery and maritime rights.

See Reports of Cases Argued and Determined in the Supreme Court of Louisiana, ed. by M.M. Robinson, New York 1845, pp. 335-339.

136 Joshua Bates (1788-1864) was born in Weymouth, Massachusetts. He was an international financier - the owner of Baring Bank. See U. Jack, The story of Joshua Bates, "The Sacred Heart Review" 1918, vol. LIX, No. 31, pp. 11-12.

${ }_{137}$ See J.B. Moore, op. cit., p. 417. 


\section{Bibliography}

\section{Printed sources}

Abridgment of the Debates of Congress, from 1789 to 1856: From 1789 to 1856, ed. by H.T. Benton, New York 1850.

British and Foreign State Papers, 1842-1843, vol. XXXI, London 1858.

Correspondence the Slave Trade with Foreign Powers, published by W. Clowes and Sons, London 1842.

Message from the President of the United States, $24^{\text {th }}$ Congress, $2^{\text {nd }}$ Section, No. 174, Washington 1835.

Message from the President of the United States, in compliance with a resolution of the Senate, in relation to the seizure and detention of the brigs Enterprise, Encomium and Comet, 25 ${ }^{\text {th }}$ Congress, $3^{\text {rd }}$ Section, No. 216, Washington 1838.

Parliamentary Papers, vol. XXVIII, published by H.M. Stationery Office, 1842.

Register of Debates in Congress: Comprising the leading debates and incidents of the second session of the Eighteenth Congress, vol. X, Washington 1834.

Reports of Cases Argued and Determined in the Supreme Court of Louisiana, ed. by M.M. Robinson, New York 1845.

Report of decisions of the commission of claims under the convention of February 8 , 1853, between the United States and Great Britain, transmitted to the senate by the president of the United States, August 11, 1856, Washington 1856.

Reports of International Arbitral Awards, vol. XXIX, New York 2012.

The African Repository and Colonial Journal, vol. XI, published by the American Colonization Society, Washington 1835.

The Creole Case and Mr. Webster's Dispatch: With the Comments of the N.Y. American, ed. by W. Jay, New York 1842.

The Diplomatic and Official Papers of Daniel Webster, while Secretary of State, New York 1848.

Treaties and other International Acts of the United States of America, vol. II (Documents 1-40: 1776-1818), ed. by H.D. Miller, Washington 1931.

\section{References}

Adams D., Lord Ashburton and the Treaty of Washington, "The American Historical Review" 1912, vol. XVII, No. 4, pp. 764-782.

Adams T.J., Dictionary of American History, New York 1940.

Bartnicki A., Michałek K., Rusinowa I., Encyklopedia historii Stanów Zjednoczonych Ameryki (od Deklaracji Niepodległości do współczesności), Warsaw 1992.

Benton H.T., Benton Thomas Hart: Thirty Years' View, New York 1856.

Burrage H.S., Maine in the Northeastern Boundary Controversy, Portland 1919.

Channing E.W., The Duty of the Free States; or Remarks Suggested by the Case of the Creole, London 1842. 
Downey T.A., The Creole Affair: The Slave Rebellion that Led the United States and Great Britain to the Brink of War, Maryland 2014.

Giddings J.R., History of the Rebellion: Its Authors and Causes, New York 1864.

Gordon H.T., The Treaty of Washington, Concluded August 9, 1842, by Daniel Webster and Lord Ashburton, Berkeley 1908.

Hicks D., Dr. Channing and the Creole Case, "The American Historical Review" 1932, vol. XXXVII, pp. 516-525.

Horne G., Negro Comrades of the Crown: African Americans and the British Empire Fight the US before Emancipation, New York 2012.

Howell J., John Armfield, Slave-trader, "Tennessee Historical Quarterly" 1943, vol. II, No 1, pp. 3-29.

Jack U., The story of Joshua Bates, "The Sacred Heart Review" 1918, vol. LIX, No. 31, pp. 7-8.

Jervey E.D., Huber C.H., The Creole Affair, "The Journal of Negro History" 1980, vol. LXV, No. 3, pp. 196-211.

Johnson W., White lies: Human property and domestic slavery aboard the slave ship Creole, "Atlantic Studies" 2008, vol. V, No. 2, pp. 237-263.

Jones D.W., The Influence of Slavery on the Webster-Ashburton Negotiations, "The Journal of Southern History" 1956, vol. XXII, No. 1, pp. 48-58.

Jones H., Crucible of Power: A History of American Foreign Relations to 1913, Maryland 2002.

Jones H., To the Webster-Ashburton Treaty: A Study in Anglo-American Relations, 1783-1843, Carolina 1977.

Jones H., Rakestraw A.D., Prologue to Manifest Destiny: Anglo-American Relations in the 1840s, Delaware 1997.

Kaufman W., Macpherson S.H., Britain and the Americas: Culture, Politics, and History, California 2005.

Kerr-Ritchie J.R., Rebellious Passage: The Creole Revolt and America's Coastal Slave Trade, Cambridge 2019.

Levy J., Freaks of Fortune: The Emerging World of Capitalism and Risk in America, Massachusetts 2012.

Libby D.J., Slavery and Frontier Mississippi, 1720-1835, Mississippi 2004.

Ludlum P.R., Joshua R. Giddings, Radical, "The Mississippi Valley Historical Review" 1936, vol. XXIII, No. 1, pp. 49-60.

Marley F.D., Historic Cities of the Americas: An Illustrated Encyclopaedia, vol. I (The Caribbean, Mexico, and Central America), California 2005.

Moore J.B., A Digest of International Law, vol. II, Washington 1906.

Moore J.B., History and Digest of the International Arbitrations to which the United States Has Been a Party: Together with Appendices Containing the Treaties Relating to Such Arbitrations, and Historical and Legal Notes on Other International Arbitrations Ancient and Modern, and on the Domestic Commissions of the United States for the Adjustment of International Claims, vol. IV, Washington 1898. 
The problem of the abolition of slavery... 137

Morris B.R., Encyclopedia of American History, New York 1982.

Perkins B., Castlereagh and Adams: England and the United States, 1812-1823, California 1964.

Perkins B., The Cambridge History of American Foreign Relations, vol. I (The Creation of a Republican Empire, 1776-1865), New York 1985.

Pond S., The Spanish Dollar: The World's Most Famous Silver Coin, "Bulletin of the Business Historical Society" 1941, vol. XV, No. 1, pp. 12-16.

Remini R.W., Andrew Jackson: The Course of American Democracy, 1833-1845, Baltimore-London 1984.

Riley S., Peters T.B., Homeward Bound: A History of the Bahamas Islands to 1850 with a Definitive Study of Abaco in the American Loyalist Plantation Period, Florida 2000.

Rodriguez J.P., Slavery in the United States: A Social, Political, and Historical Encyclopaedia, vol. I, California 2007.

Rodriguez P.R., The Historical Encyclopedia of World Slavery, vol. I, California 1911.

Rugemer E.B., Slave Rebels and Abolitionists: The Black Atlantic and the Coming of the Civil War, "The Journal of the Civil War Era" 2012, vol. II, pp. 179-202.

Rupprecht A., "All We Have Done, We Have Done for Freedom": The Creole SlaveShip Revolt (1841) and the Revolutionary Atlantic, "International Review of Social History" 2013, vol. LVIII, pp. 253-277.

Sale M.M., The Slumbering Volcano: American Slave Ship Revolts and the Production of Rebellious Masculinity, Durham-London 1997.

Sang N.V., The British-American Diplomacy in Searching for the Northeast Boundary in Maine and New Brunswick, 1820-1846, "Annals of the University of Cracovia. History" 2018, vol. II, No. 34, pp. 35-48.

Sang N.V., The Caroline Affair and the Diplomatic Crisis between Great Britain and the United States, 1837-1841, "Prawo i Polityka" 2018, No. 8, pp. 73-83.

Sang N.V., The question of Oregon in British-American relations, 1818-1846, "Koło Historii" 2017, No. 21, pp. 43-58.

Sang N.V., The Reconstruction of the British-American Relations: from the American Revolutionary War to the War of 1812, "UED Journal of Social Sciences, Humanities and Education" 2019, vol. IX (V), pp. 50-58.

Savage S.W., The Origin of the Giddings Resolutions, "Ohio Archaeological and Historical Quarterly” 1936, vol. XLV, pp. 28-39.

Schermerhorn J.L., The Business of Slavery and the Rise of American Capitalism, 1815-1860, New Haven-London 2015.

Thomas E.M., William Cabell Rives and the British Abolitionists, "The Virginia Magazine of History and Biography" 1981, vol. LXXXIX, No. 1, pp. 64-66.

Upchurch T.A., Abolition Movement, California 2011.

Woodell W., Slavery and Anti-slavery: A History of the Great Struggle in both Hemispheres with a view of the Slavery Question in the United States, New York 1852.

Woodson C.G., The Negro in Our History, Washington 1922. 


\section{INTERNET SOURCES}

Aaron Vail (1796-1878), https://history.state.gov/departmenthistory/people/ vail-aaron (online: 12 I 2019).

American Ambassadors to the United Kingdom, https://uk.usembassy.gov/ our-relationship/rcambex/ (online: 12 I 2019).

An Act to Prohibit the Importation of Slaves into any port or place within the jurisdiction of the United States: From and after the first day of January, in the year of our Lord one thousand eight hundred and eight, http:/ / avalon.law.yale. edu/19th_century/s1004.asp (online: 21 VI 2018).

Andrew Stevenson, https://history.house.gov/People/Listing/S/STEVENSON, -Andrew-(S000891)/ (online: 12 I 2019).

Artist to Depict Alexandria's History with Slave Ship "Enterprise", https://www. alxnow.com/2020/01/17/artist-to-depict-alexandrias-historywith-slave-ship-enterprise/ (online: 12 I 2019).

Bermuda's History from 1800 to 1899, http://www.bermuda-online.org/history1800-1899.htm (online: 11 II 2019).

Censure, http://www.oxfordreference.com/view/10.1093/acref/9780195142730. 001.0001/acref-9780195142730 (online: 21 VI 2018).

Charles Sumner, https://www.history.com/topics/19th-century/charles-sumner (online: 21 VI 2018).

First Annual Message, https://www.presidency.ucsb.edu/documents/first-annual-message-3 (online: 18 IV 2019).

Francis Cockburn, http://www.biographi.ca/en/bio/cockburn_francis_9E.html (online: 21 VI 2018).

Our History, https://www.bahamas.com/our-history (online: 12 I 2019).

Sir Francis Cockburn (1780-1868) - Canada, Belize, Bahamas and Dover, https:/ / doverhistorian.com/2017/02/11/sir-francis-cockburn-canada-belize-bahamas-and-dover/ (online: 21 VI 2018).

Slavery Abolition Act, https://www.britannica.com/topic/Slavery-Abolition-Act (online: 20 I 2019).

Spanish dollar, https:/ / en.wikipedia.org/wiki/Spanish_dollar (online: 14 I 2019).

The Bahamas Islands, West Indies, https://www.britannica.com/place/The-Bahamas (online: 12 I 2019).

The Creole Case (1841), http:/ /www.blackpast.org/gah/creole-case-1841 (online: 21 VI 2018).

The Slavery Abolition Act of 1833, https: / /www.thehistorypress.co.uk/articles/ the-slavery-abolition-act-of-1833/ (online: 20 I 2019).

William Ellery Channing, https://theodora.com/encyclopedia/c/william_ellery_ channing.html (online: 21 VI 2018).

William Ellery Channing, https://www.britannica.com/biography/William-ElleryChanning (online: 21 VI 2018). 
The problem of the abolition of slavery... 139

William Preston, https://www.encyclopediavirginia.org/media_player?mets_filename=evm00002634mets.xml (online: 21 VI 2018).

William Rufus King, $13^{\text {th }}$ Vice President (1853), https://www.senate.gov/artandhistory/history/common/generic/VP_William_R_King.htm (online: 21 VI 2018).

NGuyen Van SAng

UNIWERSYTET W DA NANG

Jolanta A. Daszyńska

UNIWERSYTET ŁÓDZKI

\section{Problem zniesienia niewolnictwa i praw morskich na statkach Stanów Zjednoczonych w relacjach brytyjsko-amerykańskich w pierwszej połowie XIX wieku}

W artykule zostały przeanalizowane nabrzmiałe konflikty w anglo-amerykańskich relacjach dotyczacych kwestii niewolnictwa i praw morskich w okresie od 1831 do 1842 r. Sa one oparte na analizie monografii, raportów, postanowień traktatowych oraz korespondencji amerykańskich i brytyjskich dyplomatów od momentu tzw. incydentu Kormeta (Cormet) w 1831 r. do podpisania traktatu Webstera-Ashburtona w $1842 \mathrm{r}$. W artykule zostały poruszone trzy najważniejsze sprawy, mianowicie kwestie statków: Kormeta, Encomium, Enterprise, Hermosa i Kreola jako międzynarodowych problemów w relacjach brytyjsko-amerykańskich, poglądy obu państw na kwestię zniesienia niewolnictwa, prawa morskie, jak również dyskusja na temat tego, jak rozwiązać powstałe konflikty morskie, które związane były bezpośrednio $z$ kwestią przewożenia niewolników. W artykule ukazano, że przewóz niewolników na amerykańskich statkach stał się powodem do podjęcia nadzwyczajnych przedsięwzięć, które nie miały miejsca w dotychczasowych bilateralnych stosunkach. Gdy po raz pierwszy amerykańskie statki $z$ niewolnikami dopłynęły do brytyjskich kolonii $z$ uwagi na złe warunki pogodowe i bunt niewolników na pokładzie, to $z$ uwagi na to, że do tej pory ani USA, ani Wielka Brytania nie miały do czynienia $z$ podobnymi przypadkami, w efekcie żadnej ze stron nie udało się znaleźć jednolitego poglądu. Dopiero pod presja sporu granicznego dotyczacego Maine i Nowego Brunszwiku podjęto rozwiązania, które uchroniły oba kraje przed rozpoczęciem konfliktu zbrojnego. Podjęto tymczasowe rozwiązania dotyczace niewolników i praw morskich, ale sprawy międzynarodowe związane $z$ amerykańskimi statkami przewożacymi niewolników przyczyniły się do otworzenia drogi regulującej prawa morskie w stosunkach brytyjsko-amerykańskich. Była to nagląca potrzeba.

Słowa kluczowe: Wielka Brytania, Stany Zjednoczone Ameryki, Kormet, Encomium (Chwalba), Enterprise (Przedsięwzięcie), Hermosa, Creole (Kreol), Daniel Webster, Lord Ashburton, niewolnictwo, prawa morskie. 